\title{
CHANGES IN RABBIT MEAT SAUSAGES QUALITY CONTAINING DEFATTED SOY MEAL DURING COLD STORAGE.
}

\author{
ABDEL AZIZ, HANAA A. ${ }^{1}$, S.A.S. HALLABO ${ }^{2}$ AND F.A. EL-WAKEIL ${ }^{2}$ \\ 1. Meat and Fish Technology Research Department, Food Technology Research \\ Institute, ARC, Giza, Egypt. \\ 2. Food Science and Technology Department, Faculty of Agriculture, Cairo Univ., \\ Egypt
}

(Manuscript received 17 May 2011)

\begin{abstract}
Because rabbits are characterized by high reproductivity, rapid growth, marked ability of utilizing vegetable wastes and roughages as well as high fiber rations, rabbit meat might be aid in preparation of new products. In this investigation, sausage was prepared of rabbit meat without and with replacement of $20 \%$ meat with equal amount of diluted defatted soy meal (DSM) at the ratio (1:2 DSM to water). Then moisture, protein, fat, ash, fiber and carbohydrates contents, the emulsifying capacity (EC), the water holding capacity (WHC), the plasticity and the cooking (boiling and frying) losses, total soluble nitrogen (TSN), total volatile nitrogen (TVN) content and thiobarbituric acid (TBA) values and tenderness and color measurements were determined at zero time and during cold-storage as indicator on the changes in chemical composition, physical and sensory properties respectively, to study the quality properties of rabbit meat sausages containing ( $0 \%$ and $20 \%$ DSM). From the results, it could be noticed that the replacement of meat by DSM increased moisture, ash, fiber and carbohydrates contents, EC, WHC, plasticity and tenderness and decreased protein and fat contents, the cooking (boiling and frying) losses, TSN, TVN content, TBA values and the intensity of the red color at zero time. During cold-storage of the prepared sausages it could be noticed that the moisture and protein contents, EC, WHC, plasticity, TSN, tenderness and the intensity of the red color were found to decrease progressively and the fat, ash, fiber and carbohydrates contents, the cooking (boiling and frying) losses, TVN content and TBA values were apparently increased, but the rate of decrease and increase was less for sausage containing 20 $\%$ DSM.
\end{abstract}

Keywords: Rabbit meat sausage, defatted soy meal (DSM), quality and cold-storage.

\section{INTRODUCTION}

The utilization of soybeans is gradually increasing in order to provide the expanding world population with either protein, fat or both. Thus recent surge of interest in developing protein foods containing soybeans in one practical approach to the solution of protein food problems, particularly in developing countries or those which have some lack in proteins in general and animal proteins in particular. Soy products also are used as a low cost substitute in meat and poultry products. Food 
service, retail and institutional (primarily school lunch and correctional) facilities regularly use such "extended" products. Extension may result in diminished flavor, but fat and cholesterol are reduced. Vitamin and mineral fortification can be used to make soy products nutritionally equivalent to animal protein, the protein quality is already roughly equivalent Hoogenkamp, (2005).

Meat is an excellent source of many nutrients, especially protein, vitamins $B$, iron and zinc. As a nutrient dense food, meat provides major nutritive contributions to your diet relative to the amount of calories it contains. For example, a 3 ounce cooked portion of lean beef containing 195 calories would provide $25 \mathrm{~g}$ of protein, $9 \mathrm{~g}$ of fat, over one-third of your daily requirement for zinc and nearly $15 \%$ of your daily iron needs. In addition to its high protein content, meat provides an important source of high quality protein (Boyle, 1994).

Rabbit meat is an important source of vitamin B. Consumption of $100 \mathrm{~g}$ of rabbit meat contributes to $8 \%$ of daily vitamin $B 2,12 \%$ of vitamin $B 5,21 \%$ of vitamin B6, and $77 \%$ of vitamin B3 requirements, and provides a fulfillment of the daily vitamin B12 requirement as reported by (Combes 2004).

The proportion of cut-up and further processed products should increase in the next years. As with poultry, this shift towards further processed products in Europe will soon underscore the necessity for higher standards in rabbit meat in order to improve sensory characteristics and functional properties. Complex products such as sausages, breaded products and fully cooked heat-and-serve items require an understanding of the contribution of rabbit meat to these products as well as their influence on sensory properties of the food (Barbut, 2002).

Fouda, (1986) prepared protein isolates from defatted soybean meal. It was found that defatted soybean meal had the following composition: $6.40 \%$ moisture, $87.20 \%$ protein, $0.25 \%$ fat, $0.19 \%$ fiber, $3.56 \%$ ash and $2.40 \%$ carbohydrates. Amino acid composition, $\mathrm{gm} / 16 \mathrm{gm} \mathrm{N}$ ) was 12.01 leucine + isoleucine , 5.20 phenylalanine, 4.92 valine, 1.33 methionine, 3.70 tyrosine, 4.16 threonine, 6.01 lysine, 1.58 cystine and 1.30 tryptophan. Then studied effect of the addition of soybeans on the quality properties of meat products during storage at $4^{\circ} \mathrm{C}$. It was found that the addition of soybeans for meat products led to improvement of the quality properties. During storage at $4^{\circ} \mathrm{C}$. the moisture, TN, WHC and plasticity decreased, while fat, ash, TVN and TBA value increased of all samples, but the rate of decrease and increase was less with samples which contain soybeans and all samples of sausages were organoleptically acceptable, regardless of the decrease in scores for the test sausages and the spoilage occurred after 31 days (at $4^{\circ} \mathrm{C}$.) for all samples.

Sausage is a prepared food, usually made from ground meat animal fat. Salt, spices ,sometimes with other ingredients such as herbs), typically packed in a casing, 
sausage making is a traditional food preservation technique traditionally, casings are made of animal intestine though are now often synthetic, some sausage are cooked during processing of the casing, sausage may be preserved by curing, drying in cool air and smoking (Boyle, 1994).

\section{MATERIALS AND METHODS}

\section{Materials:}

Male rabbits, Giza sp , Lepus Cuniculus ) 10 weeks old and about $2 \mathrm{kgs}$ in weight, were obtained from the Ministry of Agriculture. These rabbits were slaughtered by a sharp knife, left for bleeding. The head, skin and internal organs were removed, then the carcasses were rapidly washed with tap water. After the excess water drained, the meat of the whole carcasses was separated, minced by a home mincer and then used directly for preparation of sausages.

Defatted soy meal (DSM) was purchased from ,Extracted Oils Co., Damanhour plant) DSM, with $12 \%$ moisture, was finely powdered in the laboratory by using a mill.

Spices ,black pepper, cumin, cubeb, nutmeg, cardamom, cloves and garlic) were obtained from the local market. Each spice was powdered in the laboratory by using a mill. Then a mixture of the powdered spices was prepared as follows: $5.62 \%$ black pepper, $11.22 \%$ cumin, $22.44 \%$ cubeb, $0.22 \%$ nutmeg, $2.24 \%$ cardamom, $2.24 \%$ cloves and $56.06 \%$ garlic, this recipe was used according to El-Dashlouty, ,1978).

\section{Methods :}

Preparation of sausages :

The formula used for emulsion type sausages preparation were made from fresh rabbit meat, reported by El-Dashlouty, (1978) was as follows: $67 \%$ minced fresh meat $+15 \%$ minced fat tissues $+15 \%$ water (as ice) $+2.25 \%$ sodium chloride + $0.16 \%$ sodium nitrate $+0.09 \%$ sodium nitrite $+0.50 \%$ spices mixture. Sodium nitrate and sodium nitrite were dissolved in a small amount of water , on the expense of used ice) before being added to the formula. The ingredients were mixed ,emulsified) using a laboratory emulsifier ,Hobbart Kneading machine) for sausages and this was carried out for $8-10$ minutes. The obtained emulsion was stuffed in previously cleaned and prepared natural mutton casings. Meat-DSM sausage prepared by replacement of $20 \%$ of the fresh meat with an equal amount of rehydrated DSM (DSM : water, $1: 2 \mathrm{~W} / \mathrm{V}$ ). Sausage samples were analysed at zero time and other samples were packaged in polyethylene bags and stored by cold-storage at $4^{\circ} \mathrm{C}$. ,analysis were carried out weekly until spoilage took place and this was judged by the development of off-odor) . 


\section{Physical analysis :}

Emulsifying capacity, (EC) of meats was determined according to the method described by Webb et. al., (1970). Water holding capacity (WHC) and plasticity of samples were measured using the method of Golavin, ,1969). The cooking loss and frying loss of the prepared samples were determined and calculated according to AMSA, ,1995). The Warrer-Bratzler shear force apparatus was used to measure the tenderness of meats, whereas, low shear values indicated high tenderness as reported by Herring, 1976). The color of meats was colorimetrically measured according to the method recommended by Husaini, et. al., (1950).

\section{Chemical analysis :}

Moisture, protein, fat and ash contents of meats were determined by the standard methods as reported in the A.O.A.C (2005). Total carbohydrates content was determined as percentage, by calculating the difference between one hundred and the sum of moisture, protein, fat and ash percentage. Total soluble nitrogen ,TSN) was determined according to the method described by Soloviev, 1966$)$. Thiobarbituric acid ,TBA) value was determined as described by Egan, et. al., ,1981) and total volatile nitrogen ,TVN) as indicators of the quality was determined according to the method published by Winton and Winton ,1958).

\section{RESULTS AND DISCUSSION}

Table 1. Changes in chemical composition of rabbit sausage containing , $0 \%$ and 20 $\%$ DSM) during cold-storage at $4^{\circ} \mathrm{C}$. for 28 days.

\begin{tabular}{|c|c|c|c|c|c|c|c|c|c|c|c|c|}
\hline \multirow{4}{*}{$\begin{array}{c}\text { Time } \\
\text { of } \\
\text { storage }\end{array}$} & \multicolumn{2}{|c|}{ Moisture } & \multicolumn{2}{|c|}{ Protein } & \multicolumn{2}{|c|}{ Fat } & \multicolumn{2}{|c|}{ Ash } & \multicolumn{2}{|c|}{ Fiber } & \multicolumn{2}{|c|}{ Carbohydrates } \\
\hline & $0 \%$ & $20 \%$ & $0 \%$ & $20 \%$ & $0 \%$ & $20 \%$ & $0 \%$ & 20 & $0 \%$ & 20 & $0 \%$ & $20 \%$ \\
\hline & DSM & DSM & DSM & DSM & DSM & DSM & DSM & $\%$ & DSM & $\%$ & DSM & DSM \\
\hline & & & & & & & & DSM & & DSM & & \\
\hline 0 & 67.63 & 68.94 & 13.56 & 12.06 & 16.64 & 16.21 & 1.83 & 1.94 & 0.05 & 0.20 & 0.29 & 0.65 \\
\hline 7 & 67.24 & 68.41 & 12.94 & 11.81 & 17.18 & 16.72 & 1.92 & 2.09 & 0.06 & 0.23 & 0.66 & 0.74 \\
\hline 14 & 66.54 & 67.87 & 12.50 & 11.50 & 17.80 & 16.93 & 2.05 & 2.14 & 0.06 & 0.26 & 1.05 & 1.30 \\
\hline 21 & 65.93 & 67.32 & 12.06 & 11.06 & 18.43 & 17.56 & 2.12 & 2.23 & 0.07 & 0.28 & 1.39 & 1.55 \\
\hline 28 & 65.27 & 66.70 & 11.69 & 10.81 & 19.09 & 17.89 & 2.23 & 2.28 & 0.07 & 0.30 & 1.65 & 2.02 \\
\hline
\end{tabular}

Data in Table (1) shows the changes in moisture, protein, fat, ash, fiber and carbohydrates contents as indicators on the changes in chemical composition of rabbit 
sausage containing , $0 \%$ and $20 \%$ DSM) during cold-storage at $4{ }^{\circ} \mathrm{C}$. for 28 days. It could be noticed that the replacement of $20 \%$ meat with equal amount of DSM raised the moisture, ash, fiber and carbohydrates contents and lowered the protein and fat contents of sausages as reported by Fouda, (1986). During cold-storage of the prepared sausages it was found that the moisture and protein contents were found to decrease progressively and the fat, ash, fiber and carbohydrates contents were apparently increased, probably because of loss in moisture and/or protein breakdown. Also at the end of the storage period the influence of added DSM recorded for unstored samples was still obvious.

Table 2. Changes in physical properties of rabbit sausage containing , $0 \%$ and $20 \%$ DSM) during cold - storage at $4^{\circ} \mathrm{C}$. for 28 days.

\begin{tabular}{|c|c|c|c|c|c|c|c|c|c|c|}
\hline \multirow{3}{*}{$\begin{array}{l}\text { Time of } \\
\text { storage }\end{array}$} & \multicolumn{2}{|c|}{ EC } & \multicolumn{2}{|c|}{ WHC } & \multicolumn{2}{|c|}{ Plasticity } & \multicolumn{2}{|c|}{ Boiling loss } & \multicolumn{2}{|c|}{ Frying loss } \\
\hline & $0 \%$ & $20 \%$ & $0 \%$ & $20 \%$ & $0 \%$ & $20 \%$ & $0 \%$ & $20 \%$ & $0 \%$ & $20 \%$ \\
\hline & DSM & DSM & DSM & DSM & DSM & DSM & DSM & DSM & DSM & DSM \\
\hline 0 & 69.8 & 78.5 & 1.35 & 1.27 & 4.25 & 4.72 & 13.19 & 10.23 & 31.01 & 24.31 \\
\hline 7 & 66.6 & 76.4 & 1.63 & 1.45 & 4.03 & 4.35 & 15.17 & 11.42 & 35.64 & 26.74 \\
\hline 14 & 63.5 & 74.5 & 1.94 & 1.76 & 3.73 & 4.06 & 15.98 & 12.29 & 37.79 & 29.69 \\
\hline 21 & 61.2 & 72.2 & 2.05 & 1.93 & 3.27 & 3.53 & 17.12 & 13.74 & 38.69 & 32.26 \\
\hline 28 & 59.6 & 70.8 & 2.27 & 2.10 & 2.69 & 3.08 & 20.16 & 15.68 & 42.98 & 34.85 \\
\hline
\end{tabular}

The results in Table (2) shows the changes in the emulsifying capacity (EC), the water holding capacity (WHC), the plasticity and the cooking ,boiling and frying) losses as indicator on the changes in physical properties of rabbit sausages containing , $0 \%$ and $20 \%$ DSM) during cold-storage at $4{ }^{\circ} \mathrm{C}$. for 28 days. It was obvious that the replacement of $20 \%$ meat with equal amount of DSM raised the emulsifying capacity and improved the water holding capacity and plasticity, and lowered the boiling and frying losses of sausage samples as reported by Fouda, (1986). During cold-storage emulsifying capacity, water holding capacity and plasticity were found to decrease progressively and the boiling and frying losses were increased of all samples, but the rate of decreasing and increasing was less for sausage contains DSM. The emulsifying capacity (EC) was decreased, this could be due to the continuous decrease in protein 
solubility (TSP) as recorded in Table,3) than sausage without DSM as found by Volkert and Klein, 1979) that there a strong positive linear correlation between protein solubility and emulsifying capacity of proteins in general and in sausages in particular. In this connection, soybean protein showed markedly high emulsifying capacity. However, the emulsion stability was found to decrease by cold storage which might be the result of not only the decrease of protein solubility, but also because of some loss in protein and some increase of fat in final formula (Table,1). Finally, the emulsifying capacity was found to be highest at any given time of cold-storage for rabbit sausage, particularly when $20 \%$ of meat was substituted with DSM. The water holding capacity (WHC) and plasticity were found to decrease for all samples, but it was found that at any given time of cold storage, meat- DSM sausage showed the highest WHC and plasticity than meat sausage, these results agree with those reported by Fouda, (1986).When, the cooking ,boiling and frying) losses were found to increase for all samples as reported by Fouda, (1986) that this might be due to that the changes in cooking loss were found to follow the changes of water holding capacity for both meat and meat-DSM sausages, but it could be noticed that at any given time of cold storage, meat- DSM sausage showed the lowest the cooking ,boiling and frying) losses than meat sausage as reported by Fouda, (1986) that he incorporation of DSM in sausage reduced the cooking losses.

Table 3. Changes in chemical properties of rabbit sausage containing , $0 \%$ and $20 \%$ DSM) during cold - storage at $4^{\circ} \mathrm{C}$. for 28 days.

\begin{tabular}{|c|c|c|c|c|c|c|}
\hline \multirow{2}{*}{$\begin{array}{c}\text { Time of } \\
\text { storage }\end{array}$} & \multicolumn{2}{|c|}{ TSN } & \multicolumn{2}{c|}{ TVN } & \multicolumn{2}{c|}{ TBA } \\
\cline { 2 - 7 } & $0 \%$ & $\begin{array}{c}20 \% \\
\text { DSM }\end{array}$ & $\begin{array}{c}0 \% \\
\text { DSM }\end{array}$ & $\begin{array}{c}20 \% \\
\text { DSM }\end{array}$ & $\begin{array}{c}0 \% \\
\text { DSM }\end{array}$ & $\begin{array}{c}20 \% \\
\text { DSM }\end{array}$ \\
\hline 0 & 1.79 & 1.68 & 4.20 & 3.50 & 0.11 & 0.08 \\
\hline 7 & 1.74 & 1.62 & 11.20 & 9.80 & 0.23 & 0.12 \\
\hline 14 & 1.72 & 1.60 & 16.94 & 16.94 & 0.39 & 0.20 \\
\hline 21 & 1.66 & 1.57 & 20.02 & 18.48 & 0.55 & 0.43 \\
\hline 28 & 1.65 & 1.56 & 23.80 & 22.40 & 0.85 & 0.74 \\
\hline
\end{tabular}

Results in Table ,3) shows changes in total soluble nitrogen ,TSN), total volatile nitrogen (TVN) and thiobarbituric acid (TBA) values as indicator on the changes in 
chemical properties of rabbit sausage containing ,0 \% and $20 \%$ DSM) during cold storage at $4^{\circ} \mathrm{C}$. for 28 days. It could be noticed that total soluble nitrogen, TSN) was higher for meat sausage than for meat-DSM sausage, might be due to the decrease of protein content associated with the substitution ,Table,1), and as the time of coldstorage progressed, the level of TSN was found to decrease of all samples, but the meat-DSM sausage showed lower TSN reductions, due to that the end products of lipids oxidation usually bind with protein molecules rendering them insoluble, or rather less soluble and this could cause the reduction in TSN as reported by, Bayomy, 1986). From results in Table (3) it could be noticed that admixing $20 \%$ DSM caused some decrease in level of TVN in produced sausage, possibly because of the lower original content of TVN in DSM as compared with that usually found in different meats as found by Fouda, (1986), who reported that TVN was higher in meat sausages than soybean-meat sausages and during cold-storage, there was observe increasing in the TVN levels for all samples, but the rate of increase was less for samples containing DSM and at the onset of spoilage, after 28 days at $4{ }^{\circ} \mathrm{C}$., Table 3) meat-DSM sausage showed relatively lower TVN than meat sausage as originally prepared. Also from results in Table, 3 noticed that the substitution of meat with DSM caused some decrease in the TBA values of sausage before storage. Such decrease could be due to the possibility of DSM containing some natural antioxidations which could retard lipids oxidation and consequently reduced TBA values ,Ziprin et. al., (1981) and during coldstorage of the all sausages, the TBA values were found to increase, indicating possible lipids oxidation, but the rate of increase was less for samples containing DSM as found by Fouda, (1986) and at the end of cold storage, the sausage containing DSM had the lowest TBA value, indicating less possible of lipids oxidation.

Table 4. Changes in tenderness and color of rabbit sausage containing ,0\% and $20 \%$ DSM) during cold - storage at $4^{\circ} \mathrm{C}$. for 28 days.

\begin{tabular}{|c|c|c|c|c|}
\hline \multirow{2}{*}{$\begin{array}{c}\text { Time of } \\
\text { storage }\end{array}$} & \multicolumn{2}{|c|}{ Tenderness } & \multicolumn{2}{c|}{ Color } \\
\cline { 2 - 5 } & $0 \%$ & $20 \%$ & $0 \%$ & $20 \%$ \\
DSM & DSM & DSM & DSM \\
\hline 0 & 3.0 & 2.8 & 0.20 & 0.16 \\
\hline 7 & 3.5 & 3.0 & 0.13 & 0.12 \\
\hline 14 & 4.1 & 3.5 & 0.12 & 0.11 \\
\hline 21 & 4.4 & 3.9 & 0.10 & 0.08 \\
\hline 28 & 4.5 & 4.2 & 0.08 & 0.07 \\
\hline
\end{tabular}

The results in Table (4) shows changes in tenderness and color as indicator on the changes in sensory properties of rabbit sausage containing , $0 \%$ and $20 \%$ DSM) 
during cold - storage at $4^{\circ} \mathrm{C}$. for 28 days. It could be noticed that sausage prepared from a mixture containing $20 \%$ DSM was more tender than the value found for meat sausage. This coincides with the results reported by Robert, (1975) who found that frankfurter prepared with soy protein had lower shear force values (high tender) and this was ascribed to the dilution effect of soy protein on myofibrillar and stroma proteins responsible for toughness in meat in general and sausages in particular. Also, the improvement in tenderness of meat-DSM sausage, might be due to some increase in the water holding capacity (Table,2) causing a dilution effect or even a more tender feeling on shewing. With advancement of cold-storage, the tenderness of all sausage samples was decreased as reported by Fouda, ,1986), could be possibly due to some dryness (loss of moisture), some decrease in the water holding capacity or some decrease in protein solubility. Similar results, found in moisture, TSN and WHC, could lead to similar conclusions and explanations. From the results in ,Table,4) it could be noticed that the intensity of the red color was higher for meat sausage than for meatDSM sausage, this could be expected that the incorporation of DSM in the prepared sausages could lower the intensity of the red color the end product, yet the reduction in the color of the produced sausages was not quite similar. Such a finding was found at any given time of the refrigerated sausages where the red color intensity of such sausages gradually deceased. Fouda, (1986) reported that due to oxidative changes of pigments, the red color intensity decreased with advancement of cold-storage period of meat products containing different meat substitutes.

\section{REFERENCES}

1. AMSA. 1995. Research guidelines for cookery, sensory evaluation and instrumental tenderness measurements of fresh beef. American Meat Sci. Assoc., Chicago, USA.

2. A.O.A.C. 2005. Official Methods of Analysis of AOAC International. $18^{\text {th }}$ ed., published by AOAC International, Gaithersburg. Maryland, USA

3. Barbut, S. 2002. Poultry meat processing and product technology. In: Poultry products processing. An industry guide, CRC Press, pp. 1-29.

4. Bayomy, A. H. 1986. Studies on the preservation of some meat by freezing. Ph. D. Thesis, Faculty of Agric., Moshtohor, Zagazig Univ., Zagazig, ARE.

5. Boyle, E. 1994. Identifying sausages, Department of Animal Sciences and Industry, Kansas State University. C.F., Pakistan Journal of Nutrition 8 ,4): 332-334, 2009).

6. Combes, S. 2004. Nutritional value of rabbit meat: a review. INRA prod. Anim.17 (5): 373- 383. 
7. Egan, H., R. S. Kirk and R. Sawyer. 1981. Pearson's Chemical Analysis of Foods. $8^{\text {th }}$ ed. Churchill Livingstone. Longman Group Limited U.K.

8. El-Dashlouty, A. A. 1978. Studies on the quality of some meat products. Ph. D. Thesis, Faculty of Agric., Moshtohor, Zagazig Univ., Zagazig, Egypt.

9. Fouda, ZMA. 1986. Chemical and technological studies on meat substitutes. Ph. D. Thesis, Faculty of Agric., Zuez Canal Univ., Ismailia, Egypt.

10. Golavin, A. M. 1969. Control of fish products. Pishcevaio Permish Lemest Publishers, Moscow ,in Russian).

11. Herring, H. K. 1976. Evaluation of beef texture, objective methods for food evaluation, A Symposium, 7, National Academy of Sci., Washington, DC, USA.

12. Hoogenkamp, H. W. 2005. Soy protein and formulated meat products. Wallingford, Oxon, UK: CABI Pub. ISBN 0-85199-864-X.

13. Husaini, S. A., F. F. Deatherage and L. E. Kunkle. 1950. Studies on meat, II observations on relation of biochemical factors to changes in tenderness. Food Technology, 4, $366-369$.

14. Robert, M. 1975. The functionality of binders in meat emulsion. J. Food Sci., 40, 736- 739.

15. Soloviev, V. E. 1966. Aging of meat . Food Industry pub., Moscow.(C.F, Hanaa, A. Abdel Aziz. 1990. M,Sc. Thesis, Faculty of Agriculture, Cairo Universty, Giza, Egypt).

16. Volkert, M. A. and B. P. Klein. 1979. Protein dispersibility and emulsion characteristics of four soy products. A paper presented at the $38^{\text {th }}$ Annual Meeting of the Institute of Food Technology, Dallas, Tx., june 4-7 1978. and published in the Institute of Food Technologists pub., 0022- 1147/ 79/ 00010093502, 25/0,1979).

17. Webb, N. B., F. J. Ivey, H. B.Craig, V. A. Jones and R. J. Monroe. 1970. The measurement of emulsifying capacity by electrical resistance, J. Food Sci., $35,501-504$.

18. Winton, A. L. and R. B.Winton. 1958. Oxide distillation volumetric method for the determination of total volatile nitrogen. The Analysis of Foods, P.848.John, Wiley and Sons, New York. Chapmann and Hall. London.

19. Ziprin, Y. A., K. S. Rhee, Z. L. Carpenter, R. L. Hostler, R. N. Terrel and K. C. Rhee. 1981. Glandless cottonseed, peanut and soy protein ingredients in ground beef patties, Effect on rancidity and other quality factors. J. Food Sci., $46,58-62$.

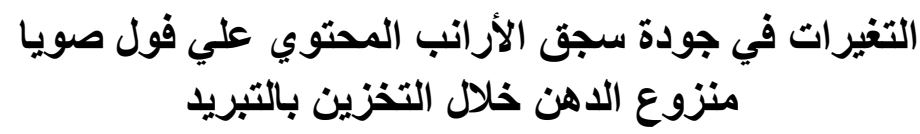




\section{هناء عبد الفتاح عبد العزيز1 ، سعد أحمد حلابو22 ، فتح الله أحمد الوكيل3 \\ 1. قسم بحوث تكنولوجيا اللحوم والأسماك, معهُ بحوث تكنولوجيا الأغذية , مركز البحوث \\ الزراعبة , جيزة , مصر \\ 2. قسم تكنولوجيا وعلوم الأغذية, كلبة الزرراعة جامعة القاهرة, مصر}

تتميز الأرانب بالقدرة العالية علي الإنجاب و النمو السريع وهي من أكثر الحيوانات انتفاعا

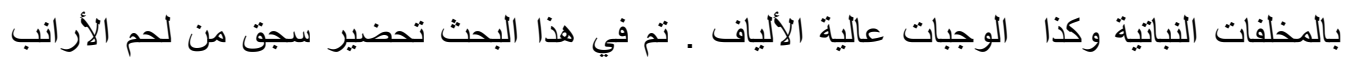
بدون إضافة فول الصويا وكذللك بإستبدال 20\% من اللحم بكمية مساوية من فول الصويا منزوع

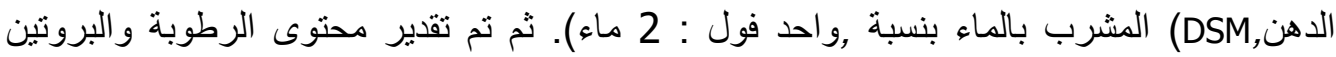

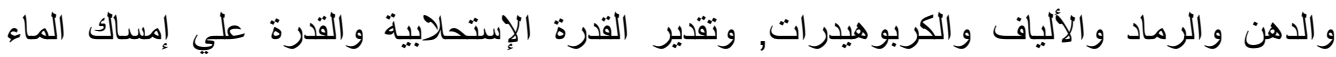

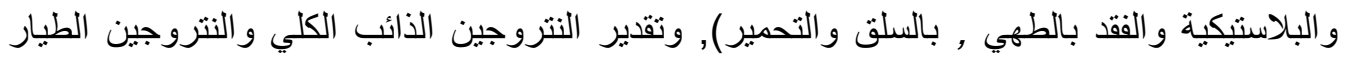

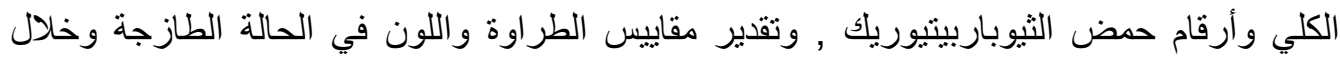
التخزين بالتبريد كدليل علي التغيرات في التركيب الكيمائي وفي الخصائص الطبيعية والكيمائية و الحسية علي الترنيب , لاراسة خصائص جودة سجق لحم الأرانب المحتوي علي ,صفر و20\%

من النتائج , بمكن ملاحظة أن إستبدال اللحم بفول الصويا منزوع الدهن أدي إلي زيادة محتوي الرطوبة والرماد و الألياف و الكربو هيدرات و القدرة الإستحلابية و القدرة علي إمساك الماء و البلاستيكية

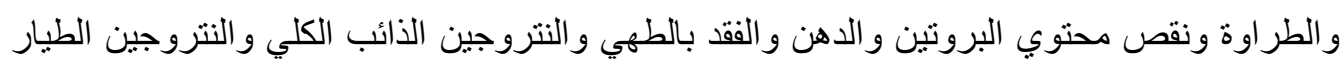

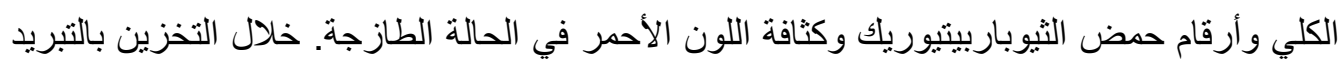

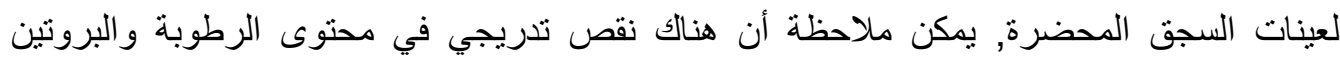

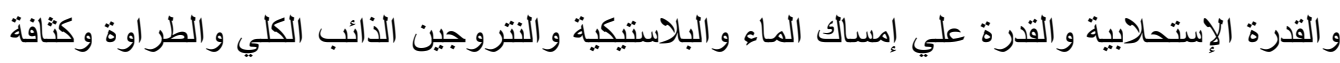

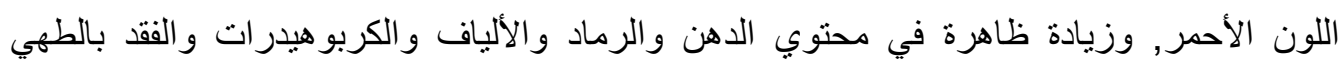

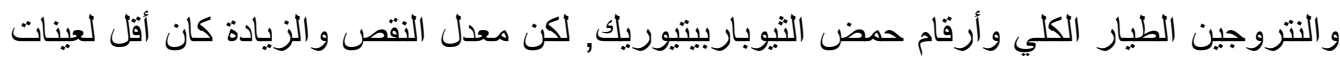
السجق المحتوي علي فول الصويا منزوع الدهن. 